\title{
DETERMINAN KINERJA KARYAWAN (STUDI KASUS PADA POLITEKNIK ILMU PELAYARAN SEMARANG)
}

\author{
${ }^{1)}$ Ulin Ulfa \\ ${ }^{2)}$ Sri Yuni Widowati \\ ${ }^{3)}$ Aprih Santoso \\ ${ }^{1,2,3)}$ Universitas Semarang \\ 1) ulin_ulfa@yahoo.com \\ ${ }^{2)}$ sriyuniwidowati@usm.ac.id \\ aprihsantoso@usm.ac.id
}

\begin{abstract}
ABSTRAK
Tujuan dari penelitian ini untuk menguji efektivitas penerapan hubungan antar karyawan dan kondisi fisik lingkungan terhadap kinerja karyawan pada Politeknik Ilmu Pelayaran Semarang. Adapun teknik analisis data menggunakan analisis regresi linier berganda. Penelitian ini menggunakan data primer. Populasi sekaligus sampel dalam penelitian ini sebanyak 67 karyawan akademik Politeknik Ilmu Pelayaran Semarang. Hasil pengujian koefisien determinasi total menunjukkan 50,4\% perubahan variabel dependen mampu dijelaskan oleh variabel independen, sedangkan sisanya 49,6\% dijelaskan oleh variabel-variabel lain di luar penelitian. Hasil pengujian hipotesis secara parsial menunjukkan adanya pengaruh secara positif dan signifikan dari hubungan antar manusia dan kondisi fisik lingkungan terhadap kinerja
\end{abstract}

Kata Kunci : Hubungan antar karyawan, Lingkungan , Kinerja

\section{PENDAHULUAN}

Sebuah instansi pada hakikatnya merupakan sekelompok manusia yang saling bekerja sama dalam rangka mencapai tujuan bersama yang telah ditetapkan sebelumnya. Keberhasilan suatu perusahaan dalam persaingan ditentukan oleh sumber daya yang dimilikinya terutama sumber daya manusianya (Hadi, et al. 2020). Suatu instansi juga dihadapkan pada tantangan besar yang selalu berkaitan dengan strategi. Salah satu strategi yang dapat ditempuh adalah dengan membentuk sumber daya manusia yang mampu bekerja secara bersama-sama, selain itu instansi harus mampu menciptakan suasana dan kondisi lingkungan yang membuat karyawan nyaman, mendorong, dan memungkinkan karyawan untuk mengembangkan kemampuan dan keterampilan secara optimal, khususnya dalam hal kinerja. Sehingga akan menciptakan suatu kelompok kerja yang solid dan memberikan pelayanan yang maksimal, dimana pada akhirnya akan meningkatkan kinerja karyawan. Kinerja merupakan hasil atau tingkat keberhasilan seseorang secara keseluruhan selama periode tertentu di dalam melaksanakan tugas dibandingkan dengan berbagai kemungkinan, seperti standar hasil kerja, target atau sasaran, atau kriteria yang telah ditentukan terlebih dahulu dan telah disepakati bersama.

Pengertian kinerja atau prestasi kerja diberi batasan oleh sebagai kesuksesan seseorang di dalam melakukan suatu pekerjaan (Priyohadi \& Ristianto, 2019). Kinerja karyawan mempengaruhi seberapa banyak atau besar mereka member konstribusi organisasi. Robbin (2006), menyatakan bahwa kinerja karyawan adalah suatu hasil yang dicapai dalam pekerjaannya menurut kriteria tertentu yang berlaku untuk suatu pekerjaan. Adanya kinerja yang tinggi, karyawan akan berusaha sebaik mungkin untuk mengatasi dan memecahkan masalah yang dihadapi dalam pelaksanaan tugas dan pekerjaannya. Untuk mencapai kinerja yang tinggi maka harus terjalin hubungan antar karyawan yang baik. Hubungan antar manusia merupakan komunikasi antar pribadi yang manusiawi yang berarti komunikasi telah memasuki tahap psikologis dimana komunikator dan komunikannya saling memahami pikiran, perasaaan, dan melakukan tindakan secara bersama. Orang sering salah menafsirkan bahwa keadaan yang tidak memuaskan itu disebabkan oleh upah yang rendah atau kondisi fisik pekerja yang kurang memuaskan. Hal tersebut memang besar pengaruhnya terhadap mutu dan produktifitas kerja. Hasil penelitian sebelumnya dari Ocran, (2014), Talumantak, et al., (2016), Polakitang, et al., (2019) menunjukkan bahwa hubungan antar karyawan berpengaruh terhadap kinerja karyawan.

Selain itu, lingkungan kerja juga menjadi salah satu yang dapat memengaruhi peningkatan kinerja karyawan (Kuswandi, 2004, Sukamto, 2013, Norianggono, et al., 2014, Wahyuningsih, 2014, Mandey \& Lengkong, 2015, Virgiyanti \& Sunuharyo, 2018, Putra \& Rahyuda, 2015). Hal ini mengidentifikasikan bahwa kondisi fisik lingkungan juga sangat diperlukan dalam rangka meningkatkan kinerja organisasi. Lingkungan kerja adalah lingkungan fisik dimana karyawan bekerja mempengaruhi kinerja, keamanan dan kualitas 
pekerjaan mereka. Lingkungan kerja merupakan bagian komponen yang sangat penting di dalam karyawan melakukan aktivitas bekerja. Ditinjau dari pemberdayaan dan pengelolaan sumber daya manusia, organisasi perlu menciptakan lingkungan yang kondusif, imbalan yang layak dan adil, beban kerja yang sesuai dengan keahlian karyawan, sikap dan perilaku dari manajer untuk membentuk produktivitas kerja karyawan. Produktivitas karyawan akan merupakan suatu salah satu kunci pendorong moral dan disiplin yang akan berpengaruh terhadap kinerja karyawan dalam mewujudkan sasaran perusahaan. Interaksi karayawan dalam lingkungan instansi merupakan hal yang tidak dapat dipisahkan yang akan menimbulkan tingkat kepuasan kerja individu, Dengan sarana hubungan yang nyaman akan lebih senang dan betah dalam menyelesaikan tugas Menyadari arti penting dari kinerja, pimpinan berupaya untuk meningkatkan dan menjaga hal tersebut pada setiap instansi yang ada. Hal ini berkaitan dengan fungsional dari organisasi pemerintah yang senantiasa mengemban tugas pelayanan bagi masyarakat umum.

Politeknik Ilmu Pelayaran (PIP) Semarang merupakan instansi pemerintah yang bergerak dalam bidang pendidikan dan ketrampilan kepelautan. Berbeda dengan perguruan tinggi pelayaran lainnya, PIP yang sejak tahun 2010 ditetapkan sebagai salah satu perguruan tinggi yang sudah menjadi Badan Layanan Umum (BLU) tidak hanya mendidik taruna-taruni tetapi PIP Semarang juga melayani pelayanan pendaftaran Diklat Keterampilan (Diktram) baik taruna maupun umum. Sehingga diharapkan instansi terkait mampu memberikan kualitas pelayanan yang baik kepada masyarakat. Namun, dengan perkembaangan zaman dan banyaknya perguruan tinggi yang sama maka PIP berusaha meningkatkan mutu pelayanan agar bisa tetap bersaing dengan perguruan tinggi besar lainnya. Gambaran berkaitannya dengan masih rendahnya kinerja karyawan pada PIP, dapat dilihat pada pencapaian realisasi kerja pegawai yang setiap tahunnya tidak mencapai target yang telah ditetapkan oleh pimpinan, misalnya masalah peningkatan pendapatan BLU instansi maupun peningkatan kualitas pelayanan karyawan. Pada tahun 2016 ditargetkan pendapatan BLU mencapai 100 milyar rupiah karena banyak terjadi penurunan peserta didik maka pendapatan BLU menurun yang disebabkan tidak tercapainya target yang akhirnya mempengaruhi pendapatan instansi. Hal tersebut terjadi dikarenakan kurangnya kerjasama yang baik antara pimpinan dengan bawahan maupun sesama karyawan yang menyebabkan tidak terjalinnya komunikasi yang baik sehingga sering kali terjadi kesalahan dalam menyelesaikan pekerjaannya. Selain itu, diketahui bahwa bagian pelayanan sertifikat kepelautan jumlah pengaduan peserta yang sertifikatnya belum terbit mengalami kenaikan tiap tahunnya. Selain itu, jumlah keluhan peserta diklat terus mengalami peningkatan selama periode lima tahun terakhir. Hal tersebut menukjukan bahwa peserta mengalami ketikpuasan dalam kinerja yang diberikan oleh karyawan PIP Semarang. Sehingga membuat peserta beralih ke tempat diklat lain. Ketidakpuasan peserta disebabkan dari kinerja pegawai, banyak sertifikat peserta yang mengalami pendingan karena hilangnya foto sehingga sertifikat belum dikeluarkan pada jangka waktu yang telah ditentukan. Belum lagi dengan kurang optimalnya kondisi lingkungan kerja mengenai konstruksi gedung, yaitu jarak antara gedung satu dengan gedung yang lain terlalu jauh. Sehingga dalam melakukan sebuah pekerjaan seorang karyawan akan merasa terhambat dan membutuhkan waktu yang lebih lama. Melihat kondisi tersebut, hubungan antar karyawan dan lingkungan kerja yang nyaman menjadi hal yang positif bagi berlangsungnya organisasi guna memberikan pelayanan yang optimal, terutama organisasi yang berorientasi pada pelanggan seperti PIP ini. Maka dari itu penelitian mengenai determinan kinerja karyawan Politeknik Ilmu Pelayaran Semarang perlu dilakukan.

Adapun rumusan masalah penelitian ini adalah apakah ada pengaruh positif dan signifikan dari hubungan antar karyawan dan kondisi fisik lingkungan terhadap kinerja karyawan PIP Semarang? sehingga akan diketahui determinan kinerja karyawan dari dua variabel independent tersebut. Tujuan penelitian ini adalah untuk menjelaskan determinan kinerja karyawan PIP Semarang dalam kaitannya dengan variabel hubungan antar karyawan dan kondisi fisik lingkungan. Dengan adanya hasil penelitian ini diharapkan dapat menjadi bahan acuan bagi PIP Semarang dalam meningkatkan kualitas pelayanan yang baik bagi masyarakat serta menjadi referensi bagi penelitian selanjutnya.

\section{LANDASAN TEORI DAN PENGEMBANGAN HIPOTESIS}

\section{Hubungan Antar Karyawan}

Hubungan antar karyawan merupakan syarat utama untuk keberhasilan suatu komunikasi baik komunikasi antar perorangan maupun komunikasi dalam instansi atau perusahaan. Penguasaan dalam menciptakan hubungan antar karyawan dalam perusahaan atau instansi akan sangat membantu sorang pimpinan dalam membantu komunikasi vertikal maupun komunikasi horisontal. Disisi lain hubungan antar karyawan merupakan 
hubungan manusiawi yang selalu dibutuhkan akan orang lain untuk bekerjasama dalam mencapai tujuan hidupnya. Hubungan yang harmonis akan membuat suasana kerja yang menyenangkan dan hal ini akan mempengaruhi semangat karyawan dalam menjalankan segala pekerjaanya.

Hubungan antar karyawan sebagai perilaku individu untuk lebih mengenal individu lainnya dalam satu organisasi. Secara sederhana, dengan adanya pendekatan perorangan di dalam organisasi, bisa meningkatkan kekompakan kinerja dalam organisasi. Karena masing-masing individu akan mencari celah yang bisa membuat mereka nyaman dalam bekerja. Dikatakan bahwa hubungan antar manusiawi itu merupakan komunikasi karena sifatnya yang orientasi pada perilaku (action oriented), hal ini mengandung kegiatan untuk mengubah sikap, pendapat, atau perilaku seseorang. Onong (2001), mengemukakan empat prinsip yang harus diperhatikan untuk mengevaluasi hubungan antar karyawan, yaitu: 1. Kebutuhan untuk bekerjasama 2. Kesiapan mental 3. Pengendalian emosional 4. Latar belakang Instrument Davis (1989), hubungan antar manusia adalah interaksi antara seseorang dengan orang lain dalam situasi kerja dan dalam organisasi kekaryawanan. Ditinjau dari kepimpinannya, yang bertanggung jawab dalam suatu kelompok merupakan interaksi orang-orang menuju situasi kerja yang memotivasi untuk bekerjasama secara produktif, sehingga dicapai kepuasan ekonomi, psikologis dan sosial. Adapun pengertian hubungan manusiawi, yakni hubungan antar manusiawi dalam arti luas dan hubungan antar manusiawi dalam arti sempit yaitu:1). Hubungan manusia dalam arti luas Hubungan antar manusia dalam arti luas yaitu interaksi antara seseorang dengan orang lain dalam segala situasi dan dalam semua bidang kehidupan, bisa dilakukan di rumah, di jalan, di dalam kendaraan umum (misal bis, kereta api) dan sebagainya. 2). Hubungan manusia dalam arti sempit Hubungan antar manusia dalam arti sempit yaitu interaksi antara seseorang dengan orang lain. Akan tetapi interaksi di sini hanyalah dalam situasi kerja dan dalam organisasi kerja (work organization).

Dalam kegiatan hubungan manusiawi ini terdapat dua jenis konseling bergantung pada pendekatan (approach) yang dilakukan. kedua jenis koseling tersebut ialah directive conseling, yakni konseling yang langsung terarah non directive conseling, yakni konseling yang tidak langsung terarah.

\section{Kondisi Fisik Lingkungan}

Lingkungan fisik bersifat nyata, lingkungan ini berkenaan dengan kondisi tempat atau ruangan (jika dalam ruangan) dan kelengkapan material atau peralatan yang diperlukan untuk bekerja. Kondisi yang dimaksud antara lain: kebersihan, penerangan, ventilasi, tata ruang (terutama pengaturan meja, kursi kerja dan lemari), warna dinding, peralatan kerja yang cukup terpelihara, dan sebagainya. Kondisi ruangan dan peralatan itu akan menimbulkan semangat kerja yang positif dan modal kerja yang tinggi, sehingga tidak mudah menimbulkan kelelahan, tidak mengganggu konsentrasi terhadap pekerjaan. Mengenai lingkungan kerja fisik yang baik, Persepsi tentang kondisi fisik lingkungan kerja tersebut adalah pandangan, pengamatan dan pemberian arti mengenai segala sesuatu yang ada di sekitar karyawan yang dapat mempengaruhi sikap kerja karyawan.

Subroto, (2005), lingkungan kerja merupakan keadaan sekitar tempat kerja baik secara fisik maupun non fisik yang dapat memberikan kesan yang menyenangkan, mengamankan, menentramkan, dan betah kerja. Faktor lingkungan yang mempengaruhi kinerja karyawan (Subroto, 2005), antara lain : a. Lingkungan kerja non fisik. b. Lingkungan kerja fisik Faktor-faktor yang termasuk lingkungan kerja yang harus diketahui dan harus diperhatikan yang berpengaruh besar terhadap semangat kegairahan

kerja antara lain pewarnaan, kebersihan, pertukaran udara, penerangan, keamanan dan kebisingan. Kondisi lingkungan yang sehat dan aman merupakan dambaan setiap orang yang akan lebih baik apabila ditunjang dengan kondisi kantor atau tempat bekerja yang baik dan peralatan yang memadai maka akan menjadikan kinerja karyawan menjadi lebih baik atau bisa juga meningkat.

\section{Kinerja Karyawan}

Robbin (2006), kinerja adalah hasil yang dicapai oleh pekerja dalam pekerjaannya menurut kriteria tertentu berlaku untuk suatu pekerjaan. Tingkat pencapaian hasil pada implementasi tugas -tugas khusus yang konkret, dapat diamati dan diukur untuk mewujudkan tujuan perusahaan (Priyohadi, 2015 dalam Mudayat \& Husen, 2020). Kesimpulannya, kinerja karyawan merupakan hasil dan keluaran yang dihasilkan oleh seorang karyawan sesuai dengan perannya dalam organisasi dalam suatu periode tertentu. Kinerja karyawan yang baik adalah salah satu faktor yang sangat penting dalam upaya instansi untuk meningkatkan produktivitas. Kinerja seorang karyawan merupakan hal yang bersifat individual, karena setiap karyawan mempunyai tingkat kemampuan yang berbeda-beda dalam mengerjakan tugasnya. 
Penilaian kinerja (performance appraisal) pada dasarnya merupakan faktor kunci guna mengembangkan suatu organisasi secara efektif dan efisien, karena adanya kebijakan atau program yang lebih baik atas sumber daya manusia yang ada dalam organisasi. Penilaian kinerja individu sangat bermanfaat bagi dinamika pertumbuhan organisasi secara keseluruhan, melalui penilaian tersebut maka dapat diketahui kondisi sebenarnya tentang bagaimana kinerja karyawan.

Penilaian kinerja karyawan khususnya dalam bidang jasa, ysitu (Robbin, 2006) : 1. Pelayanan yang kondusif 2. Kedisiplinan 3. Tanggungjawab 4. Kecepatan dan ketepatan waktu 5. Keramahan dan kesopanan 6. Hubungan yang baik dengan pelanggan 7. Kecekatan 8. Penampilan Indikator-indikator tersebut akan digunakan oleh penulis sebagai bahan pengambilan data kepada pelanggan/peserta di Politeknik Ilmu Pelayaran Semarang.

Tujuan penilaian kinerja karyawan dibagi menjadi dua: 1) Tujuan Evaluasi. 2) Tujuan Pengembangan Kontribusi hasil-hasil penilaian merupakan suatu yang sangat bermanfaat bagi perencanaan kebijakan organisasi.

\section{Pengaruh Hubungan antar karyawan terhadap kinerja karyawan}

Hubungan antar karyawan adalah komunikasi antar pribadi yang manusiawi, berarti komunikasi yang telah memasuki tahap psikologis yang komunikator dan komunikannya saling memahami pikiran, perasaan dan melakukan tindakaan bersama. Ini juga berarti bahwa apabila kita hendak menciptakan suatu komunikasi yang penuh dengan keakraban yang didahului oleh pertukaran informasi tentang identitas dan masalah pribadi yang bersifat sosial. Kinerja adalah suatu hasil kerja yang dicapai seseorang dalam melaksanakan tugas-tugas yang dibebankan kepadanya yang didasarkan atas kecakapan, pengalaman, kesungguhan serta waktu (Hasibuan ; 2010 dalam Heryanti \& Rosalita, 2018). Ocran, (2014), Talumantak, et al (2016), Polakitang, et al (2019) memiliki hubungan positif dan signifikan dengan kinerja karyawan. Hubungan positif memberikan arti bahwa semakin baik hubungan antar karyawan di dalam organisasi maka kinerja karyawan semakin baik sehingga prestasi kerja karyawanpun akan semakin meningkat. Berdasarkan uraian tersebut maka hipotesis yang dibuat penulis pada penelitian ini adalah :

H1 : Hubungan antar karyawan berpengaruh terhadap kinerja karyawan Politeknik Ilmu Pelayaran Semarang.

\section{Pengaruh Kondisi fisik lingkungan terhadap kinerja karyawan}

Lingkungan kerja adalah segala sesuatu yang ada di sekitar para pekerja dan yang dapat memengaruhi dirinya dalam menjalankan tugastugas yang dibebankan. Kondisi fisik lingkungan merupakan faktor yang penting didalam kelancaran dan kenyamanan bekerja, hal ini akan dapat meningkatkan kinerja karyawan karena kondisi fisik lingkungan ini bersifat nyata, hal ini berkaitan dengan kondisi tempat atau ruangan dan kelengkapan material atau peralatan yang diperlukan atau digunakan untuk bekerja. Edison, et al. (2016) dalam Raharjo \& Setiawan (2018), kinerja adalah hasil dari suatu proses yang dapat mengacu dan diukur selama periode waktu tertentu berdasarkan ketentuan atau kesepakatan yang telah ditetapkan sebelumnya Kuswandi (2004), Sukamto (2013), Norianggono, et al (2014), Wahyuningsih (2014), Mandey \& Lengkong (2015), Virgiyanti \& Sunuharyo (2018), Putra \& Rahyuda (2015) bahwa kondisi fisik lingkungan kerja berpengaruh terhadap kinerja karyawan. Berdasarkan uraian tersebut maka hipotesis yang dibuat penulis pada peneitian ini adalah :

H2 : Lingkungan kerja berpengaruh terhadap kinerja karyawan Politeknik Ilmu Pelayaran Semarang.

\section{METODOLOGI PENELITIAN}

Variabel dalam penelitian ini meliputi:

1. Variabel bebas (Variabel independen)

a. Hubungan Antar Karyawan (X1), yaitu hubungan antar manusia adalah hubungan manusiawi itu merupakan suatu komunikasi karena sifatnya yang orientasi pada perilaku (action oriented), hal ini mengandung kegiatan untuk mengubah sikap, pendapat, atau perilaku seseorang (Onong, 2001). Adapun indikatornya adalah : 1. Kebutuhan untuk bekerjasama 2. Kesiapan mental 3. Pengendalian emosional 4. Latar belakang

b. Kondisi Fisik Lingkungan (X2), yaitu kondisi Fisik Lingkungan adalah pandangan, pengamatan dan pemberian arti mengenai segala sesuatu yang ada disekitar karyawan yang dapat mempengaruhi sikap kerja karyawan (Hasibuan, 2012). Adapun indikatornya adalah : 1. Kebersihan 2. Penerangan 3. Sirkulasi udara 4. Tata ruang 5. Pewarnaan 6. peralatan kerja yang tersedia. Adapun indikatornya 
adalah: 1. Pelayanan yang kondusif 2. Kedisiplinan 3. Tanggung jawab 4. Kecepatan dan ketepatan waktu. 5. Keramahan dan kesopanan 6. Hubungan yang baik dengan pelanggan 7. Kecekatan 8. Penampilan.

2. Variabel Terikat (Variabel Dependen)

Kinerja Karyawan (Y) yaitu suatu hasil yang dicapai oleh pekerja dalam pekerjaan menurut kriteria tertentu berlaku untuk suatu pekerjaan (Robbins, 2006).

Populasi dalam penelitian ini adalah seluruh pegawai Politeknik Ilmu Pelayaran Semarang yang berjumlah 67 orang. Teknik sampling dalam penelitian ini adalah sensus, dimana elemen semua populasi dijadikan sampel. Alasan pemilihan sampel menggunakan metode sensus karena jumlah populasi kurang dari 100 responden. Sedangkan jumlah pegawai akademik di Politeknik Ilmu Pelayaran Semarang berjumlah 67 orang. Metode pengumpulan datanya melalui kuesioner/daftar pertanyaan, yaitu dengan cara memberi seperangkat pertanyaan atau pertanyaan tertulis kepada responden. Dengan kuesioner ini, responden diminta untuk mengisi jawaban dari setiap pertanyaan yang tersedia dengan skala pengukuran 1 sampai dengan 5. Skala pengukuran menggunakan skala likert dengan pilihan: 1. Sangat Setuju $(\mathrm{SS})=5$. 2. Setuju $(\mathrm{S})=4$ 3. Kurang Setuju $(\mathrm{KS})=34$. Tidak Setuju $(T S)=25$. Sangat Tidak Setuju $($ STS $)=1$.

Analisis data meliputi:

1. Uji validitas dan reliabitas

Uji validitas dan reliabilitas digunakan untuk analisis butir item kuesioner. Suatu kuesioner dinyatakan valid jika pertanyaan kuesioner mampu mengungkapkan kinerja karyawan. Uji signifikasi dilakukan dengan membandingkan nilai $r$ hitung dengan $r$ tabel. Jika $r$ hitung lebih besar dari $r$ tabel, maka pertanyaan tersebut dinyatakan valid, sebaliknya bila $r$ hitung kurang dari $r$ tabel maka pertanyaan tersebut dinyatakan tidak valid. Suatu konstruk atau variabel dikatakan reliabel bila nilai alpha Cronbach $>0,6$.

2. Uji normalitas, uji multikolinearitas, dan heteroskedastisitas

Uji normalitas untuk melihat apakah data tersebut memiliki distribusi normal atau tidak dapat menggunakan uji statistc non parametrik kolomagorovsmirnov uji ini digunakan untuk menguji apakah residual terdistribusi secara normal atau tidak. Jika tingkat signifikansi diatas 0,05 maka dapat disimpulkan bahwa data terdistribusi normal. Uji multikolinearitas jika nilai Tolerance lebih dari 0,100 atau nilai VIF kurang dari 10, maka hal ini menunjukkan adanya multikolonieritas sedang uji heteroskedastisitas dengan melihat jika probabilitas 36 signifikansinya di atas tingkat kepercayaan 5\%, maka dapat disimpulkan model regresi tidak mengandung heteroskedastisitas

3. Analisis regresi linier berganda

$\mathrm{Y}=\mathrm{a} 1+\mathrm{b} 1 . \mathrm{X} 1+\mathrm{b} 2 \cdot \mathrm{X} 2+\mathrm{e} 1$

Dimana :

X1 : Hubungan antar karyawan

$\mathrm{X} 2$ : Kondisi fisik lingkungan

b1,b2, : Koefisien regresi variabel bebas.

Y : Kinerja karyawan

e : Error

4. Uji parsial (uji t)

Uji t digunakan untuk menguji signifikansi hubungan antara variabel $\mathrm{X}$ dan $\mathrm{Y}$ secara individual atau parsial. Kriteria pengujian dengan tingkat signifikansi 5\% adalah jika t hitung <t table maka Ho diterima yang berarti variabel independen secara individual tidak mempengaruhi variabel dependen dan jika sebaliknya Ho ditolak.

5. Analisis koefisien determinasi $\left(\mathrm{R}^{2}\right)$

Koefisien determinasi $\left(\mathrm{R}^{2}\right)$ untuk mengetahui tingkat ketepatan dalam analisis regresi, dimana hal yang ditunjukkan oleh besarnya koefisien $\left(\mathrm{R}^{2}\right)$ antara 0 - 1. Apabila koefisien determinasi semakin mendekati satu, maka variabel bebas berpengaruh terhadap variabel terikat. Selain itu koefisiensi determinasi dipergunakan untuk mengetahui persentase variabel terikat yang disebabkan oleh variabel bebas.

\section{HASIL PENELITIAN}

Uji Validitas Data

Tabel 1 . Uji Validitas 


\begin{tabular}{lcccc}
\hline Variabel & Item & r tabel Komponen Matrix & Keterangan \\
\hline Hubungan Antar Karyawan (X1) X1.1 & 0,240 & 0.867 & Valid \\
X1.2 & & 0.827 & Valid \\
& X1.3 & 0.878 & Valid \\
X1.4 & 0.889 & Valid \\
Kondisi Fisik Lingkungan (X2) & X2.1 & 0,240 & 0,854 & Valid \\
& X2.2 & 0,863 & Valid \\
& X2.3 & 0,874 & Valid \\
& X2.4 & 0,853 & Valid \\
& X2.5 & 0,821 & Valid \\
& X2.6 & 0,816 & Valid \\
Kinerja Karyawan & Y1 & 0,240 & 0,847 & Valid \\
& Y2 & 0,798 & Valid \\
& Y3 & 0,804 & Valid \\
& Y4 & 0,721 & Valid \\
& Y5 & 0,849 & Valid \\
& Y6 & 0,758 & Valid \\
& Y7 & 0,856 & Valid \\
& Y8 & 0,794 & Valid \\
\hline
\end{tabular}

Berdasarkan tabel tersebut dapat disimpulkan bahwa semua indikator variabel mempunyai koefisien korelasi dengan signifikansi lebih besar dari $r$ tabel sebesar 0,240 (Uji Satu Arah) maka valid.

\section{Uji Reliabilitas Data}

Tabel 2. Hasil Pengujian Reliabilitas

\begin{tabular}{lccc}
\hline \multicolumn{1}{c}{ Variabel } & Alpha Cronbach & Alpha Cronbach & Kriteria \\
\hline Hubungan Antar & 0.887 & 0,6 & Reliabel \\
Kondisi Fisik Lingkungan & 0.920 & 0,6 & Reliabel \\
Kinerja Karyawan (Y) & 0,921 & 0,6 & Reliabel
\end{tabular}

Tabel di atas menunjukkan Hasil uji reliabilitas tersebut menunjukkan bahwa semua variabel mempunyai koefisien Alpha yang cukup besar yaitu diatas 0,60 sehingga semua konsep pengukur masing-masing variabel dari kuesioner adalah reliable. Untuk selanjutnya item-item pada masing-masing konsep variabel tersebut layak digunakan sebagai alat ukur.

\section{Uji Normalitas}

Uji statistik lain yang dapat digunakan untuk menguji normalitas residual adalah uji stasistik nonparametrik Kolmogorov-Smirnov ( K-S ).

Tabel 3. Uji Normalitas K-S

\section{One-Sample Kolmogorov-Smirnov}

Test

\begin{tabular}{llr}
\hline & & Unstandardized Residual \\
\hline Normal Parameters & & 67 \\
& Mean & $0 \mathrm{E}-7$ \\
& Std. Deviation & 3,37107926 \\
Most Extreme Differences & Absolute &, 061 \\
& Positive &, 043 \\
& Negative &,- 061 \\
Kolmogorov-Smirnov Z & &, 495 \\
Asymp. Sig. (2-tailed) & &, 967 \\
\hline
\end{tabular}

a. Test distribution is Normal.

b. Calculated from data. 
Tabel di atas, pengujian Kolmogorov Smirnov menunjukkan nilai signifikansi yang lebih besar dari 0,05. Hal ini berarti bahwa model regresi tersebut sudah berdistribusi normal

Pengujian Multikolinieritas

Tabel 4. Pengujian Multikolinieritas

Coefficients

\begin{tabular}{lllrr}
\hline & & \multicolumn{2}{c}{ Collinearity Statistics } \\
Model & & Tolerance & VIF \\
\cline { 2 - 5 } & & (Constant) &, 856 & 1,168 \\
& & Hubungan Antar Karyawan (X1) &, 856 & 1,168 \\
\hline
\end{tabular}

Hasil pengujian menunjukkan bahwa nilai tolerancedari semua variabel bebas memiliki diatas 0,05 dan nilai VIF dibawah 10 dari semua variabel bebas memiliki nilai yang lebih kecil dari 10. Hal ini berarti bahwa variabel-variabel penelitian tidak menunjukkan adanya gejala multikolonieritas dalam model regresi.

\section{Pengujian Heteroskedastisitas}

Tabel 5. Hasil Pengujian Heteroskedastisitas

\begin{tabular}{llccc}
\hline & & Standardized Coefficients & \\
Model & & Beta & T & Sig. \\
\hline 1 & (Constant) & & 2,013 &, 048 \\
& Hubungan Antar Karyawan (X1) &, 090 &, 675 &, 502 \\
& Kondisi Fisik Lingkungan (X2) &,- 205 & $-1,548$ &, 127 \\
\hline
\end{tabular}

Hasil tampilan output SPSS dengan jelas menunjukkan semua variabel independen mempunyai nilai sig $\geq$ 0,05. Jadi tidak ada variabel independen yang signifikan secara statistik mempengaruhi variabel dependen nilai absolute dari residual. Hal ini terlihat dari nilai signifikan pada tiap-tiap variabel independen seluruhnya diatas 0,05. Jadi dapat disimpulkan model regresi tidak mengandung adanya heterokedastisitas.

Analisis Regresi Linear Berganda

Tabel 6. Koefisien Regresi Linear Berganda

\begin{tabular}{llcrrr}
\hline & & Standardized Coefficients & & \\
Model & & Beta & T & Sig. \\
\hline 1 & (Constant) & & & 1,466 &, 148 \\
& Hubungan Antar Karyawan (X1) & &, 468 & 4,917 &, 000 \\
& Kondisi Fisik Lingkungan (X2) &, 386 & 4,055 &, 000 \\
\hline
\end{tabular}

\section{Persamaan Regresi}

$$
\mathrm{Y}=4,840+0,947 \mathrm{X} 1+0,488 \mathrm{X} 2+\mathrm{e}
$$

Dari model tersebut di atas menunjukkan bahwa semua koefisien regresi memiliki arah positif. Koefisien variabel terbesar terdapat pada variabel hubungan anatar karyawan yang menjadikan variabel bebas yang paling dominan mempengaruhi kinerja karyawan, sedangkan yang koefisien terkecil atau yang mempunyai pengaruh paling kecil terdapat pada variabel kondisi fisik lingkungan kerja.

\section{Uji Parsial (Uji t)}

\section{Uji Hipotesis Hubungan Antar karyawan}

Terlihat pada tabel 6, nilai signifikansi lebih kecil dari 0,05. Hal tersebut menunjukkan bahwa hipotesis 1 dalam penelitian ini diterima yang artinya hubungan antar manusia mempunyai pengaruh yang signifikan terhadap kinerja karyawan, penelitian ini mendukung hasil penelitian dari Ocran, (2014), Talumantak, et al (2016), Polakitang, et al (2019) diketahui bahwa hubungan antar karyawan memiliki hubungan positif dan signifikan dengan kinerja karyawan.

\section{Uji Hipotesis Kondisi Lingkungan Fisik}

Terlihat pada tabel 6 , nilai signifikansi lebih kecil dari 0,05 . Hal tersebut menunjukkan bahwa hipotesis 2 dalam penelitian ini diterima yang artinya kondisi fisik lingkungan mempunyai pengaruh yang signifikan terhadap kinerja karyawan, penelitian ini mendukung hasil penelitian dari Penelitian Kuswandi (2004), Sukamto (2013), Norianggono, et al (2014), Wahyuningsih (2014), Mandey \& Lengkong (2015), Virgiyanti \& Sunuharyo (2018), Putra \& Rahyuda (2015), menyimpulkan bahwa kondisi fisik lingkungan kerja berpengaruh terhadap kinerja karyawan.

Koefisien Determinasi $\left(\mathbf{R}^{2}\right)$ 
Tabel 7. Output Koefisien Determinasi

Model Summary

\begin{tabular}{llrrr}
\hline Model & R & R Square & Adjusted R Square & Std. Error of the Estimate \\
\hline 1 &, 710 &, 504 &, 489 & 3,423 \\
\hline
\end{tabular}

Dari tabel di atas hasil uji determinasi didapatkan R2 sebesar 0,504 yang artinya 50,4\% variabel kinerja karyawan dapat dijelaskan oleh variabel hubungan antar karyawan dan kondisi fisik lingkungan, sedangkan sisanya sebesar 49,6\% kinerja karyawan dapat dijelaskan oleh faktor-faktor lainnya, seperti : insentif, disiplin, komitmen organisasi, dan lain-lain.

\section{PEMBAHASAN}

\section{Pengaruh hubungan antar karyawan terhadap kinerja karyawan.}

Hasil pengujian hipotesis 1 yang diajukan dalam penelitian ini bahwa ada pengaruh dari hubungan antar manusia terhadap kinerja karyawan.Hubungan antar manusia yang baik dapat meningkatkan kinerja karyawan Politeknik Ilmu Pelayaran Semarang. Hasil penelitian ini mendukung penelitian sebelumnya yang mendapatkan bahwa hubungan antar manuusia berpengaruh positif dan signifikan terhadap kinerja karyawan, yaitu : Ocran, (2014),Talumantak, et al (2016), Polakitang, et al (2019). Namun, hasil penelitian ini berlawanan hasil yaitu tidak terdapat pengaruh signifikan antara variabel hubungan antar manusia terhadap kinerja pegawai negeri sipil pada Kantor Kecamatan Rangkui Pangkalpinang (Syajidin, et. al. 2017).

\section{Pengaruh kondisi fisik lingkungan terhadap kinerja karyawan.}

Hasil pengujian hipotesis 2 yang diajukan dalam penelitian ini bahwa ada pengaruh dari kondisi fisik lingkungan terhadap kinerja karyawan Politeknik Ilmu Pelayaran Semarang. Kondisi fisik lingkunganyang baik dapat meningkatkan kinerja karyawan. Hasil penelitian ini mendukung penelitian sebelumnya yang mendapatkan bahwa kondisi fisik lingkungan berpengaruh positif dan signifikan terhadap kinerja karyawan, yaitu : Kuswandi (2004), Sukamto (2013), Norianggono, et al (2014), Wahyuningsih (2014), Mandey \& Lengkong (2015), Virgiyanti \& Sunuharyo (2018), Putra \& Rahyuda (2015). Namun, hasil penelitian ini berlawanan hasil dengan Syajidin, et al. (2017) yang menyatakan bahwa tidak terdapat pengaruh signifikan pada variabel Lingkungan Kerja terhadap Kinerja Pegawai Negeri Sipil pada Kantor Kecamatan Rangkui Pangkalpinang.

\section{KESIMPULAN DAN SARAN}

Kesimpulan hasil penelitian ini adalah : 1) Hubungan antar karyawan memiliki pengaruh yang positif dan signifikan terhadap kinerja karyawan Politeknik Ilmu Pelayaran Semarang. Hubungan antar karyawan yang lebih baik akan membuat kinerja karyawan meningkat. 2) Kondisi fisik lingkungan memiliki pengaruh yang positif dan signifikan terhadap kinerja karyawan Politeknik Ilmu Pelayaran Semarang. Kondisi fisik lingkungan yang lebih baik akan membuat kinerja karyawan meningkat.

Adapun saran yang diberikan adalah hendaknya Politeknik Ilmu Pelayaran lebih meningkatkan kinerja karyawan yang terkait dengan hubungan dengan masyarakat (pelanggan) dan meningkatkan kerjasama karyawan secara intensif sehingga kinerja karyawan dapat lebih meningkat lagi.

\section{DAFTAR PUSTAKA}

Davis, Keith. 1989. Human Behaviour At Work 8th ed. Singapore: McGraw - Hill, Inc.

Edison, Emron, Yohny Anwar \& Imas Komariyah. 2016. Manajemen Sumber Daya Manusia. Bandung: Alfabeta

Hadi, S, Putra, AR \& Mardikaningsih, R. 2020. Pengaruh Perilaku Inovatif Dan Keterlibatan Kerja Terhadap Kinerja Karyawan, Jurnal Baruna Horizon, 3(1), 186-197.

Hardiayansyah. 2011. Kualitas Pelayanan Publik, Yogyakarta : Gava Media.

Hasibuan, Malayu Sp. 2012. Manajemen SDM Edisi Revisi Cetakan Ke Tigabelas. Jakarta : Bumi Aksara.

Heryanti. RN \& Rosalita, E. 2018. Disiplin Kerja, Pemberian Penghargaan Sertifikat Dan Pemberian Insentif Terhadap Kinerja Pegawai. Jurnal Baruna Horizon. 1(1). 1-15.

Kuswandi. 2004. Cara Mengukur Kepuasan Kerja, Jakarta : Elex Media Komputindo. 
Mandey, M, A \& Lengkong, V, P, K. 2015. Pengaruh Gaya Kepemimpinan, Komunikasi, dan Pembagian Kerja Terhadap Kinerja Karyawan Pada PT. Sinar Galesong Prima Manado. Jurnal EMBA. 3(3)

Mudayat \& Husen, AA,. 2020. Pengaruh Pelayanan Muatan Peti Kemas Dan Human Factors terhadap Kinerja Operator Rtg Di Terminal Peti Kemas Nilam. Jurnal Baruna Horizon. 3(2). 251-262

Norianggono, Yacinda C.P., Hamid, D \& Ruhana. I. 2014. Pengaruh Lingkungan Kerja Fisik dan Non Fisik Terhadap Kinerja Karyawan, Jurnal Administrasi Bisnis (JAB), 8(2), 1-10

Ocran, G, 2014, The Effect of Human Relation on Employee Performance at Benso Oil Plantation. UCC. Library.https://erl.ucc.edu.gh/jspui/bitstream/123456789/3149/1/GEORGE\%20KISI\%20OCRAN. pdf. Tanggal Akses 27 Februari 2019.

Onong, Effendy. 2001. Ilmu Teori dan Filsafat Komunikasi. Jakarta: Erlangga.

Polakitang, CF., Lengkong, VPK. \& Dotulong, LOH. 2019. Pengaruh Hubungan Antar Manusia, Beban Kerja Dan Kompensasi Tidak Langsung Terhadap Kinerja Karyawan Operasional Pada PT. BNI (Persero) Tbk Kantor Cabang Manado. Jurnal EMBA, 7(3). 2621 - 2630.

Priyohadi, Nugroho Dwi. 2015. Human Capital Management. PT Pelindo III. ISBN: 978-602-7802-23-0.

Priyohadi, Nugroho Dwi \& Ristianto, Devik. 2019. Jumlah Gang Buruh Dan Kapasitas Alat Terhadap Kinerja Bongkar Muat Curah Kering. Jurnal Baruna Horizon. 2(1). 1-10.

Putra, IBKSD \& Rahyuda, AG. 2015. Pengaruh Lingkungan Kerja Fisik Dan Stres Kerja Terhadap Kinerja Pegawai Di UPT. Pengujian Kendaraan Bermotor Dinas Perhubungan Kota Denpasar. E-Jurnal Manajemen Unud, 4(9), 2491- 2506.

Raharjo, HW \& Setiawan, INTO. 2018. Kemudahan Penggunaan Dan Kepuasan Kerja Terhadap Kinerja Pengguna Aplikasi Spiner. Jurnal Baruna Horizon. 1(1). 1-16.

Rivai, Veithzal. 2009. Manajemen Sumber Daya Manusia Untuk Perusahaan. Jakarta: Raja Grafindo Persada.

Robbins, P. Stephen. (2006). Perilaku Organisasi. Edisi Sepuluh.. Erlangga, Jakarta.

Sukamto, M.A. 2013. Pengaruh Lingkungan Kerja Fisik dan Non Fisik Terhadap Kinerja Pegawai Pada Badan Ketahanan Pangan dan Pelaksana Penyuluhan Daerah Kota Samarinda. Jurnal Paradigma, 2(2). 341 351

Suryantoro, B., Ihksan, AR. \& Haqi, M. 2019. Analisis Motivasi Dan Kepuasan Kerja Terhadap Kinerja Karyawan Pada PT Pelabuhan Indonesia Iii (Persero) Regional Jawa Timur, Jurnal Baruna Horizon. 2(2). 81-89

Syajidin, M., Yenfi \& Medinal. 2017. Analisis Pengaruh Hubungan Antar Manusia, Pelatihan Dan Lingkungan Kerja Terhadap Kinerja Pegawai Negeri Sipil (Studi Kasus Pada Kantor Kecamatan Rangkui Pangkalpinang). Jurnal Ilmiah Progresif Manajemen Bisnis (JIPMB). 15(1). 40-58.

Subroto, N. 2005. Pengaruh Pelatihan, Motivasi Dan Lingkungan Kerja Terhadap Kinerja Pegawai Dinas Peternakan Dan Perikanan Kabupaten Semarang. Unpublished Undergraduate Thesis, Program Pascasarjana Magister Manajemen, UMS. Surakarta.

Talumantak, A., Kojo, C dan Dotulong, L. O. H. 2016. Analisis Pengaruh Human Relationship Dan Beban Kerja Terhadap Kinerja Pegawai Pada Dinas Koperasi Dan Umkm Provinsi Sulawesi Utara. Jurnal Berkala Ilmiah Efisiensi, 16(01). 52-862.

Virgiyanti \& Sunuharyo, B.S. 2018. Pengaruh Lingkungan Kerja Fisik Dan Non Fisik Terhadap Kinerja Karyawan (Studi Pada Karyawan Divisi Fresh PT. Trans Retail Indonesia (Carrefour) Plaza Tangerang City). Jurnal Administrasi Bisnis (JAB). 61(2). 55-60.

Wahyuningsih, Sri. 2014. Pengaruh Lingkungan Kerja Terhadap Kinerja Pegawai pada Kantor Kecamatan Tering Kabupaten Kutai Barat, E-journal Pemerintahan Integratif, 2(1), 70-84. 